\section{Effect of Salinity on Bermudagrass Cold Hardiness}

\author{
G.C. Munshaw ${ }^{1}$ X. Zhang, and E.H. Ervin \\ Department of Crop and Soil Environmental Science, Virginia Polytechnic \\ Institute and State University, 429 Smyth Hall, Blacksburg, VA 24061
}

Additional index words. proline, osmoregulant, compatible solutes, Cynodon dactylon

\begin{abstract}
Bermudagrass [Cynodon dactylon (L.) Pers.] is widely used along its northern limit of adaptation. However, cold hardiness and winter survival are common concerns facing turfgrass managers in these areas. The objective of this study was to determine the effects of moderate salinity applications on bermudagrass cold hardiness. Two trials were conducted in Summer 2002. The cultivar Princess was seeded into pots in a glasshouse at a rate of $24 \mathrm{~kg} \cdot \mathrm{ha}^{-1}$. Pots received a weekly solution of 20-20-20 at a rate of $4.9 \mathrm{~kg} \cdot \mathrm{ha}^{-1} \mathrm{~N}$. Bi-weekly salinity treatments began $\approx 2$ months after germination and consisted of 0,5 , 20 , and $40 \mathrm{dS} \cdot \mathrm{m}^{-1}$ in the form of $\mathrm{NaCl}$. These treatments continued for $\approx \mathbf{8}$ weeks. Weekly quality ratings and chlorophyll fluorescence measurements showed similar results, with the high salinity treatments having the poorest quality. Soil electrical conductivity measurements showed a significant increase for the high salinity rates over the lower rates at the end of the trials. Proline concentrations increased with increasing salinity treatments in Trial 1 and were highest with the $20 \mathrm{dS} \cdot \mathrm{m}^{-1}$ rate in Trial 2. Plants were acclimated in a growth chamber, and artificial freezing tests revealed that the 5 and $20 \mathrm{dS} \cdot \mathrm{m}^{-1}$ treatments had the highest percentage of regrowth after freezing. These results indicate that moderate applications of salt or the use of effluent water prior to hardening may be an important way to increase bermudagrass cold hardiness.
\end{abstract}

Bermudagrass is the predominant turfgrass for lawns, athletic fields, and golf courses throughout the southern half of the United States. Bermudagrass, a warm-season species, is limited in its northern use to parts of the transition zone because of a lack of cold hardiness. It is a popular choice in the southwestern United States, as irrigation water may often contain salts and ions, such as $\mathrm{Na}^{+}$, $\mathrm{B}$, and $\mathrm{Cl}^{-}$, that can have negative effects on turfgrass growth. Bermudagrass has shown good tolerance to salinity and can survive in sodic soils better than most turfgrass species (Mancino and Pepper, 1994).

Many studies have looked at the effect of salt stress on membrane lipid characteristics. Allakhverdiev et al. (1999) and Yu et al. (1998) found increases in fatty acid unsaturation due to high salt concentrations in cyanobacteria (Synechocystis ssp.) and barley (Hordeum vulgare L.), respectively. Jain et al. (2001) reported an increase in lipid peroxidation under salt stress in groundnut (Arachis hypogaea L.).

Taiz and Zeiger (1998) stated that there are two processes involved in osmotic adjustment in response to changes in water potential. The first is an accumulation of ions in the vacuole. Ions, such as $\mathrm{K}^{+}, \mathrm{Ca}^{2+}$, and $\mathrm{Na}^{+}$, can accumulate in the cell to decrease water potential without adjusting turgor pressure during dry or saline conditions. At high levels these ions can be

Received for publication 10 Mar. 2003. Accepted for publication 1 Aug. 2003. The authors wish to thank Rocky Lemus and Ryan Jarrells for their assistance with various parts of this research. The authors also wish to thank J. Syvertsen and Y. Levy for their assistance with proline determination.

${ }^{1}$ To whom reprint requests should be addressed. E-mail address: gmunshaw@vt.edu toxic to the cytosol, so they must be sequestered in the vacuole. Because these ions are compartmentalized in the vacuole, other solutes such as organic acids must accumulate in the cytoplasm as water potential equilibrium must be maintained in the cell. These organic acids, known as compatible solutes, include proline, glycine betaine, sucrose, and sorbitol (Nilsen and Orcutt, 1996; Taiz and Zeiger, 1998). Compatible solutes are able to build up to high levels in the cytoplasm without interfering with cell metabolism. Jain et al. (2001) state that proline is the "... primary cytoplasmic osmoticum responsible for the observed decline in the solute potential."

During cold stress, plants also accumulate sucrose and other simple sugars as well as proline and glycine betaine, which are reported to stabilize membranes and act as osmolytes to maintain water balances between the cell and the environment (Holmstrom et al., 2000; Nilsen and Orcutt, 1996).

Hincha (1994) reports that $\mathrm{NaCl}$ applications on non-hardened plants can induce cold hardening in many mono- and dicotyledonous species. Different stresses can have very similar effects on biochemical processes in plants. The processes that occur during cold acclimation are very similar to those that occur during salinity stress. These similarities include stabilization of membranes, accumulation of specific proteins, sugars, and osmolytes (Buchanan et al., 2000). Due to these similarities, we hypothesized that cold hardiness of bermudagrass may be increased by exposure to salt stress prior to hardening temperatures.

Our objectives were to: 1) determine the effects of saline irrigation on bermudagrass canopy growth, visual quality, photochemical efficiency, and proline concentration; and
2) determine if these treatments and effects were associated with changes in freezing tolerance.

\section{Materials and Methods}

Plant material and establishment. Two glasshouse studies were conducted between Apr. and Nov. 2002. A seeding rate of 24.4 $\mathrm{kg} \cdot \mathrm{ha}^{-1}$ PLS of 'Princess' bermudagrass, a relatively cold sensitive (Morris, 2002; Philley et al., 1999) cultivar supplied by Dr. C. Rogers (Seeds West Inc., Maricopa, Ariz.) was used to maximize stolon production while minimizing time to establishment (Munshaw et al., 2001). Pots of $15.2 \mathrm{~cm}$ in diameter were filled with a greens grade sand with a $\mathrm{pH}$ of 6.8. Pots were arranged in a randomized complete block with four replications and placed on an open metal mist bench. Each pot received a soluble application of $20 \mathrm{~N}-$ $9.2 \mathrm{P}-16.6 \mathrm{~K}-0.05 \mathrm{Mg}-0.0068 \mathrm{~B}-0.0036 \mathrm{Cu}-$ $0.05 \mathrm{Fe}-0.025 \mathrm{Mn}-0.0009 \mathrm{Mo}-0.0025 \mathrm{Zn}$ (Peters Professional water-soluble fertilizer general purpose 20-20-20) at seeding to provide $\mathrm{N}$ at $48.8 \mathrm{~kg} \cdot \mathrm{ha}^{-1}$. Clipping commenced (with scissors) when grass height initially reached $2 \mathrm{~cm}$, and pots were maintained at this height until maturity was reached and then left unclipped for the duration of the study.

Salinity treatments. Upon sufficient maturation, salinity treatments began by irrigating with $\mathrm{NaCl}$ concentrations of $0,5,20$, and 40 $\mathrm{dS} \cdot \mathrm{m}^{-1}$ twice weekly. A soluble solution of 20-20-20 was mixed with the salt solution once weekly to provide $4.9 \mathrm{~kg} \cdot \mathrm{ha}^{-1} \mathrm{~N}$ plus micronutrients and electrical conductivity (EC) of the soil was measured at the beginning and end of the salinity treatments by mixing a $10-\mathrm{g}$ soil sample with distilled water for $0.5 \mathrm{~h}$. EC was then measured using a conductivity meter (model 124; Thermo Orion, Beverly, Mass.). Pure water is a poor conductor of electricity and EC is based on ions dissolved in a water sample. The more salts dissolved in water, the higher the EC and osmotic pressure (Taiz and Zeiger, 1998). Quality ratings were taken weekly, using a 1-9 scale where: $1=$ brown, dead grass; $5=$ minimally acceptable; and 9 = dark green, healthy grass. Photochemical efficiency (Fv690nm/Fm690nm) was obtained using chlorophyll fluorescence. Three readings from each pot were averaged for data analysis (Zhang and Schimdt, 2000). Heights were obtained by measuring the tallest plant in each pot at the end of the study.

Acclimation and freezing treatments. After 2 months of saline irrigation, the pots were removed from the glasshouse and placed in a controlled environment chamber (Vollrath Refrigeration Division, River Falls, Md.) and acclimated using a $10-\mathrm{h}$ photoperiod at $250 \mu \mathrm{mol} \cdot \mathrm{m}^{-2} \cdot \mathrm{s}^{-1}$ photosynthetic photon flux $(P P F)$. Temperatures were $8{ }^{\circ} \mathrm{C}$ day $/ 4{ }^{\circ} \mathrm{C}$ night (Anderson et al., 1993). After 2 weeks in the chamber, the plants were prepared for placement in a freeze chamber. A 10.2-cm-diameter cup cutter sample was removed from the pots, cleaned of all soil by washing and divided into four equal samples. These samples were then placed in a freezing chamber that ramps from 8 
to $1^{\circ} \mathrm{C}$ overnight. The temperature then ramps to $-2.8^{\circ} \mathrm{C}$ over $2 \mathrm{~h}$, stays at this temperature for $0.5 \mathrm{~h}$ and a sample is removed. This process continues on ramping to -5.0 and $-7.2^{\circ} \mathrm{C}$ over the next $5 \mathrm{~h}$. Samples are then allowed to thaw in the refrigerator overnight at $4{ }^{\circ} \mathrm{C}$ and placed in the glasshouse at $22 \pm 2{ }^{\circ} \mathrm{C}$ and evaluated for regrowth. Regrowth was then estimated visually $\approx 4$ weeks after freezing (Schmidt and Chalmers, 1993). Regrowth was measured in Trial 2 only due to a lab error in Trial 1 .

Proline concentration. Additional plant samples were removed at the same time as freezing, placed in liquid $\mathrm{N}_{2}$ to halt respiration and then placed in a $-80{ }^{\circ} \mathrm{C}$ freezer for later analysis. About $0.25 \mathrm{~g}$ plant material was ground and homogenized in $10 \mathrm{~mL}$ of $3 \%$ sulfosalicylic acid and the homogenate filtered through a Whatman no. 2 filter paper. Two $\mathrm{mL}$ acid ninhidrin and $2 \mathrm{~mL}$ glacial acetic acid were added to $2 \mathrm{~mL}$ of the filtrate and incubated at $100{ }^{\circ} \mathrm{C}$ for $1 \mathrm{~h}$. The reaction terminated by placing test tubes in an ice bath. The mixture was extracted with $4 \mathrm{~mL}$ toluene and vortexed for 15-20 s. The chromophore containing toluene was warmed to room temperature and absorbance was read at $520 \mathrm{~nm}$ using toluene as the blank. Proline concentration was determined from a standard curve (Syvertsen and Smith, 1983).

Statistical design. Experimental design was a randomized complete block with four replications. Statistical analyses were performed by PROC GLM of SAS (SAS Institute, Cary, N.C.), and means were separated using least significant difference at the $\alpha=0.05$ level.

\section{Results and Discussion}

Salinity treatments significantly reduced visual turfgrass quality. Quality ratings during the first trial (Fig. 1) showed a fairly constant trend throughout the experiment with the $5 \mathrm{dS} \cdot \mathrm{m}^{-1}$ treatment having better quality than the 20 and $40 \mathrm{dS} \cdot \mathrm{m}^{-1}$ treatments, but not being different to the $0 \mathrm{dS} \cdot \mathrm{m}^{-1}$ treatment. In the second trial (Fig. 2 ), however, turfgrass quality ratings showed more variation throughout the experiment. The 5 and $20 \mathrm{dS} \cdot \mathrm{m}^{-1}$ treated pots had better quality than did the 0 and $40 \mathrm{dS} \cdot \mathrm{m}^{-1}$ treatments at nearly every observation date.

Chlorophyll fluorescence readings showed similar trends to the quality ratings, especially in Trial 1 (Figs. 3, 4). The 0 and $5 \mathrm{dS} \cdot \mathrm{m}^{-1}$ treatments mainly showed more photochemical efficiency than did the higher salinity treatments. There was a positive correlation $(r=$ $0.40^{* *}$ ) between chlorophyll fluorescence and quality ratings. Asignificant reduction in visual quality ratings and chlorophyll fluorescence with higher salinity treatments was expected because of the increase in osmotic stress on the plants. Vieira Santos et al. (2001) reported a reduction in chlorophyll content in salt stressed sunflower (Helianthus annuus L.) leaves. The moderate stress of the 5 and $20 \mathrm{dS} \cdot \mathrm{m}^{-1}$ treatments did not have a large effect on turfgrass quality. This appears to be in line with salinity stress on St. Augustinegrass [Stenotaphrum secundatum (Walt.) Kuntze] where salinity treatments as high as $32.4 \mathrm{dS} \cdot \mathrm{m}^{-1}$ improved

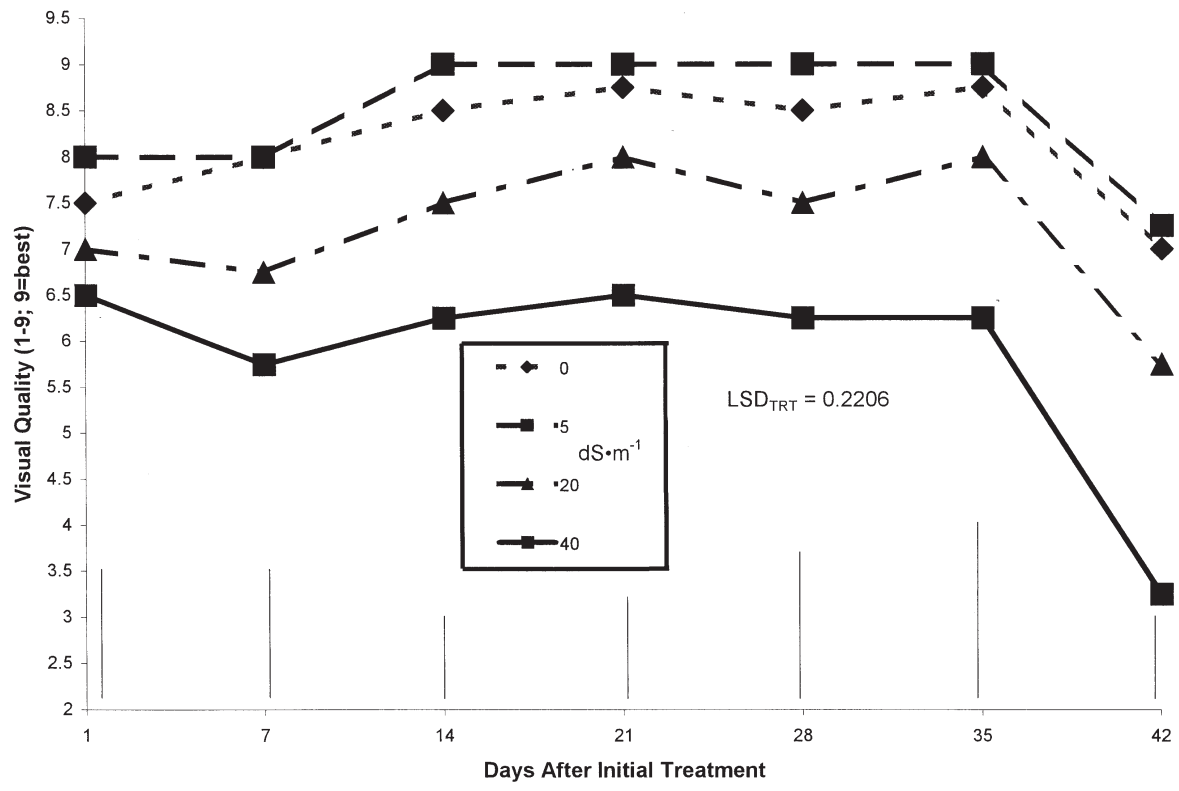

Fig. 1. Effect of salinity on turfgrass quality ratings in Trial 1 . The vertical bar represents the LSD value $(P<0.05)$.

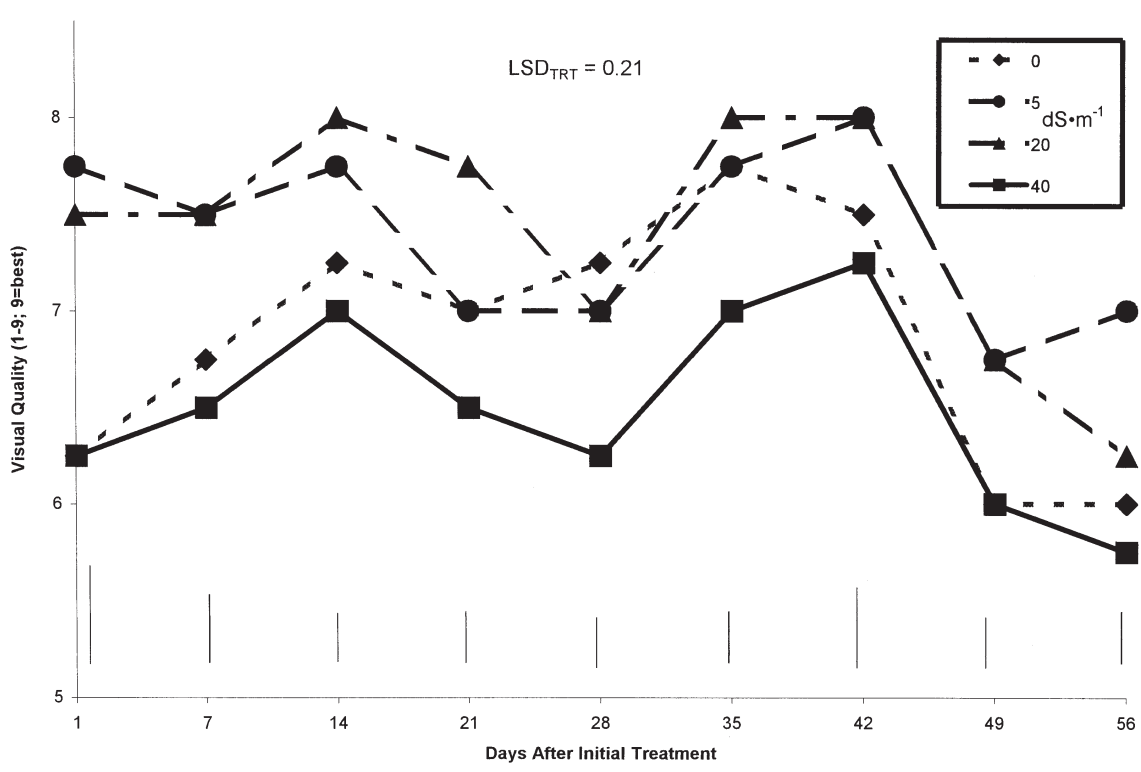

Fig. 2. Effect of salinity on turfgrass quality in Trial 2. The vertical bar represents the LSD value $(P<$ $0.05)$.

turf density and did not negatively effect leaf color (Meyer et al., 1989). However, Gaugh and Wadleigh (1944) reported a reduction in turf color and a burning of bermudagrass with high salinity.

Soil EC measurements were taken before and after salinity treatments. Prior to the addition of salt in Trial 1 (Table 1), all EC readings were low. By the end of the experiment the EC of the $5 \mathrm{dS} \cdot \mathrm{m}^{-1}$ treatment had increased $108 \%$ over the control. The 20 and $40 \mathrm{dS} \cdot \mathrm{m}^{-1}$ treatments had increased $364 \%$ and $505 \%$, respectively, over the control. The second trial (Table 1) showed that although clean sand was used, the pre-salt EC levels were much higher than they were in the first trial, but after salt applications, levels were very similar to Trial 1. Saeed (2000) reported similar results after irrigating cotton (Gossypium hirsutum L.) with salt water.
Heights were measured at the end of Trial 2 and the results were as expected. The higher salinity treatments caused a significant reduction in plant growth over the lower treatments (Table 1). Qian et al. (2000) found similar results with zoysiagrass (Zoysia sp.). With conductivity levels of $\approx 20 \mathrm{dS} \cdot \mathrm{m}^{-1}$, shoot growth inhibition occurred. Dudeck and Peacock (1993) reported 50\% top growth reductions of 'Tifway'bermudagrass (Cynodon dactylon $\times C$. transvaalensis Burtt-Davy) with conductivity levels of $33 \mathrm{dS} \cdot \mathrm{m}^{-1}$.

Proline concentrations were determined before and after salinity applications in both trials. In both trials there was a large increase in proline concentration after salinity treatment (Table 1). In the first trial the $20 \mathrm{dS} \cdot \mathrm{m}^{-1}$ salinity rate had the highest production of proline whereas in the second trial the $40 \mathrm{dS} \cdot \mathrm{m}^{-1}$ rate was the highest. The higher salinity rates were 


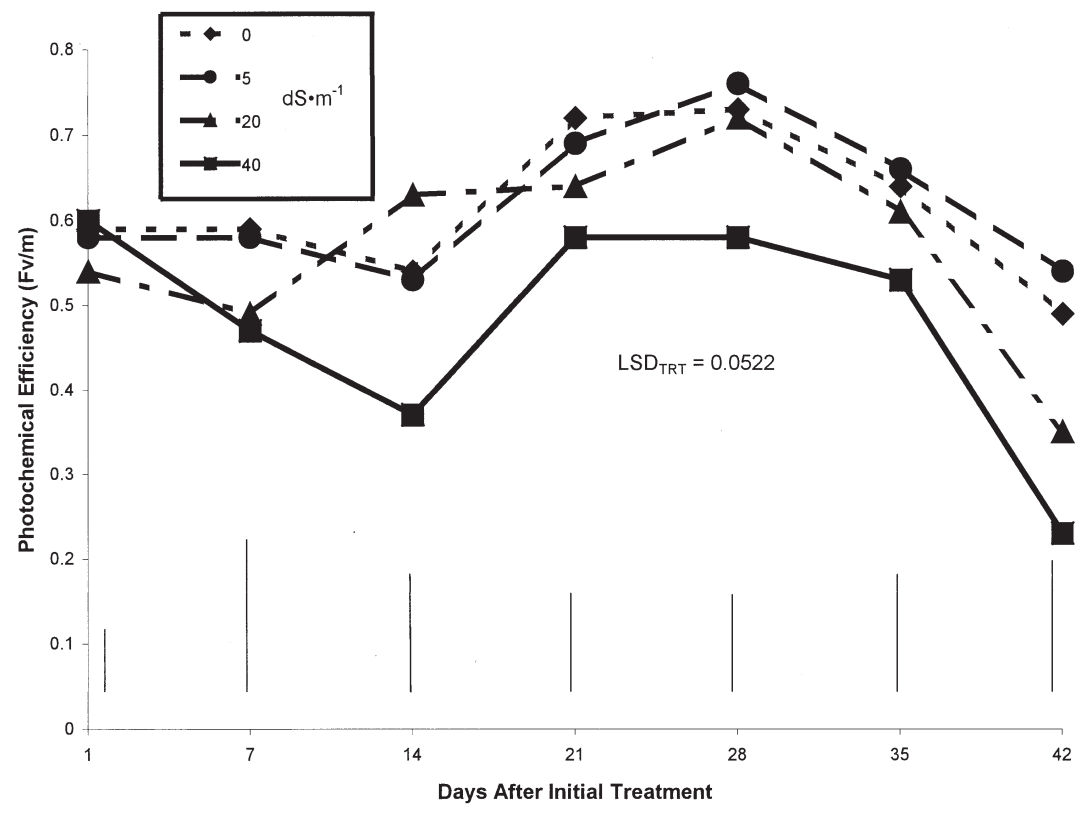

Fig. 3. Effect of salinity on photochemical efficiency in Trial 1 . The vertical bar represents the LSD value $(P<0.05)$.

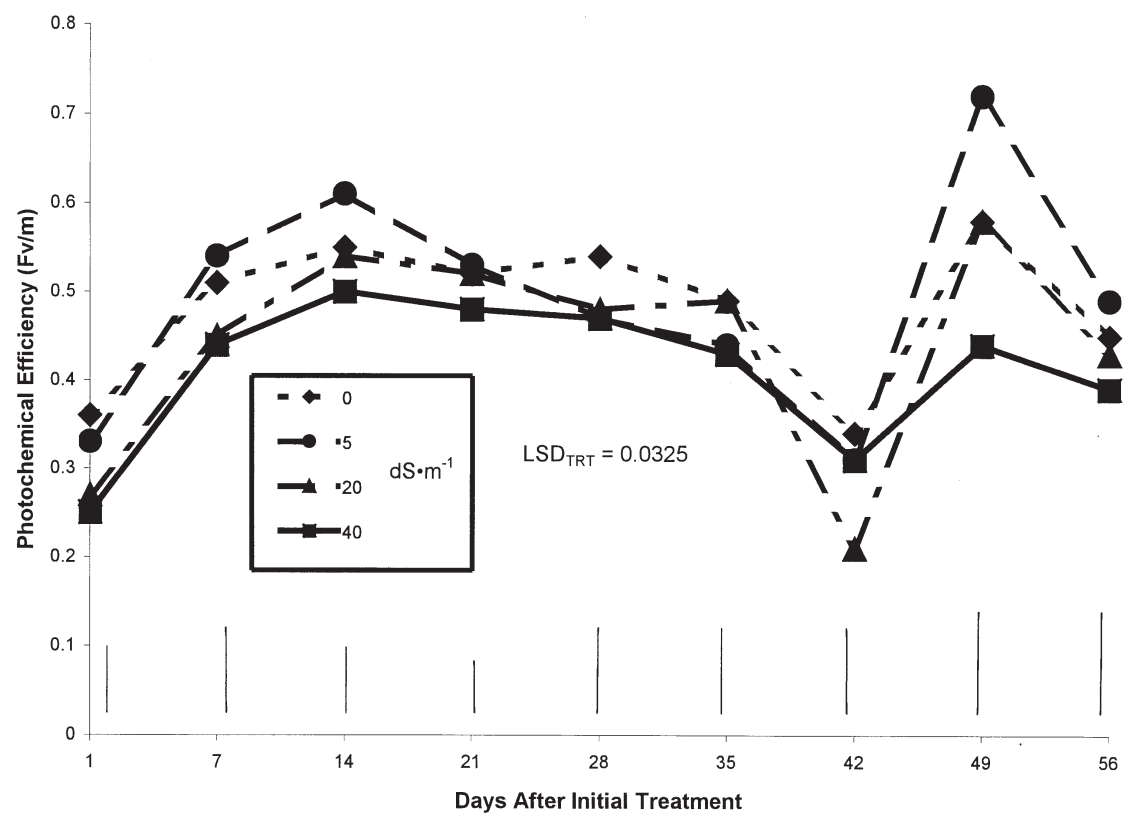

Fig. 4. Effect of salinity on photochemical efficiency in Trial 2. The vertical bar represents the LSD value $(P<0.05)$.

Table 1. Effects of added salinity on soil EC, plant proline concentration, and canopy height.

\begin{tabular}{|c|c|c|c|c|c|}
\hline \multirow{2}{*}{$\begin{array}{l}\text { Salt } \\
\text { treatment } \\
\left(\mathrm{dS} \cdot \mathrm{m}^{-1}\right)\end{array}$} & \multicolumn{2}{|c|}{$\begin{array}{l}\text { Soil EC } \\
\left(\mathrm{d} S \cdot \mathrm{m}^{-1}\right)\end{array}$} & \multicolumn{2}{|c|}{$\begin{array}{c}\text { Proline } \\
\left(\mathrm{g} \cdot \mathrm{g}^{-1}\right)\end{array}$} & \multirow{2}{*}{$\begin{array}{c}\text { Canopy ht } \\
\text { (cm) } \\
\text { Final }\end{array}$} \\
\hline & Initial $^{z}$ & Final & Initial & Final & \\
\hline \multicolumn{6}{|c|}{ Trial 1} \\
\hline 0 & $3.3 \times 10^{-4 \mathrm{ss}}$ & $2.0 \times 10^{-3} \mathrm{c}$ & $0.032^{\mathrm{Ns}}$ & $4.17 \mathrm{~b}$ & --- \\
\hline 5 & $3.7 \times 10^{-4 \mathrm{ss}}$ & $4.1 \times 10^{-3} \mathrm{bc}$ & $0.064^{\mathrm{Ns}}$ & $4.64 \mathrm{~b}$ & --- \\
\hline 20 & $4.2 \times 10^{-4 \mathrm{ss}}$ & $9.2 \times 10^{-3} \mathrm{ab}$ & $0.082^{\mathrm{Ns}}$ & $6.26 \mathrm{a}$ & --- \\
\hline 40 & $4.5 \times 10^{-4 \mathrm{ss}}$ & $1.2 \times 10^{-2} \mathrm{a}$ & $0.128^{\text {Ns }}$ & $5.55 \mathrm{ab}$ & --- \\
\hline \multicolumn{6}{|c|}{ Trial 2} \\
\hline 0 & $3.5 \times 10^{-4} \mathrm{~b}$ & $5.5 \times 10^{-4} \mathrm{~d}$ & $0.051 \mathrm{c}$ & $1.41 \mathrm{c}$ & $26.5 \mathrm{a}$ \\
\hline 5 & $2.4 \times 10^{-3} \mathrm{ab}$ & $2.6 \times 10^{-3} \mathrm{c}$ & $0.089 \mathrm{c}$ & $1.87 \mathrm{c}$ & $23.0 \mathrm{a}$ \\
\hline 20 & $4.9 \times 10^{-3} \mathrm{ab}$ & $7.7 \times 10^{-3} \mathrm{~b}$ & $0.212 \mathrm{~b}$ & $2.74 \mathrm{~b}$ & $16.1 \mathrm{~b}$ \\
\hline 40 & $7.2 \times 10^{-3} \mathrm{a}$ & $1.2 \times 10^{-2} \mathrm{a}$ & $0.313 \mathrm{a}$ & $3.81 \mathrm{a}$ & $13.1 \mathrm{~b}$ \\
\hline
\end{tabular}

${ }^{2}$ Values followed by the same letter within the same column are not significantly different $(P \leq 0.05)$. expected to produce the highest amount of proline as the plants were under higher levels of stress. Marcum and Murdoch (1994) looked at the influence of salinity in bermudagrass and five other turfgrass species and found that with increased salinity, levels of proline and glycine betaine also increased. The authors also make the statement that in five of the six species (including bermudagrass), an increase in these solutes may make a significant contribution to osmotic adjustment in the cytosol. A significant increase in proline was also observed in groundnut in response to salt stress (Jain et al., 2001). Syvertsen and Smith (1983) saw an increase of free proline in citrus (Citrus ssp.) tissues in response to drought as well as cold temperature. However, other research has shown no positive correlation between salt and proline concentrations. Syvertsen and Yelenosky (1988) were unable to correlate salinity treatment with proline concentration in citrus rootstock seedlings and Marcum (1999) found a negative correlation with proline concentrations and salinity tolerance in warm-season grasses.

Regrowth of plants after freezing was measured in the second trial. It was found that the moderate salinity treatments of 5 and $20 \mathrm{dS} \cdot \mathrm{m}^{-1}$ had the highest percentage of regrowth (Fig. $5)$. There was a positive correlation $\left(r=0.66^{* *}\right)$ between regrowth and proline concentration across all temperatures in the second trial for the 0,5 and $20 \mathrm{dS} \cdot \mathrm{m}^{-1}$ treatments only. Although the plants receiving the high rate of $40 \mathrm{dS} \cdot \mathrm{m}^{-1}$ had the highest proline concentration, they did not have the highest percentage of regrowth. This may be due to the fact that the highest salinity treatment imposes too much stress on the plants prior to freezing, resulting in a weaker plant less capable of surviving freezing temperatures. The main effects of temperature across all salinity treatments were as expected. The warmer temperatures resulted in higher percentages of regrowth in the glasshouse (Fig. 5 ). The interaction of temperature by salt was nonsignificant.

Moderate applications of salinity may have potential as a tool for increasing cold tolerance of bermudagrass. With increased use of effluent water on golf courses in the United States, turfgrass managers are concerned about overall reductions in plant health. In this study, turfgrass responses such as quality, soil EC, and height were affected to some degree over the control. The degree affected, however, varied with level of salinity. Dean-Knox et al. (1998) suggest that a salinity level of $6.0 \mathrm{dS} \cdot \mathrm{m}^{-1}$ could be used as a supplemental irrigation source as long as the water deficit was minimized. In this study a salinity level of $6.0 \mathrm{dS} \cdot \mathrm{m}^{-1}$ would have been high enough to positively effect regrowth, following freezing.

Turfgrass managers in the transition zone may at least have one beneficial effect of using effluent with a moderate salinity level (3-6 dS $\left.\cdot \mathrm{m}^{-1}\right)$ : increased cold tolerance. Proline concentration shows that the moderate $\mathrm{NaCl}$ treatments positively influence regrowth, following freezing. If proline concentrations dictate increased cold hardiness levels, then moderate stress levels may very well be ben- 

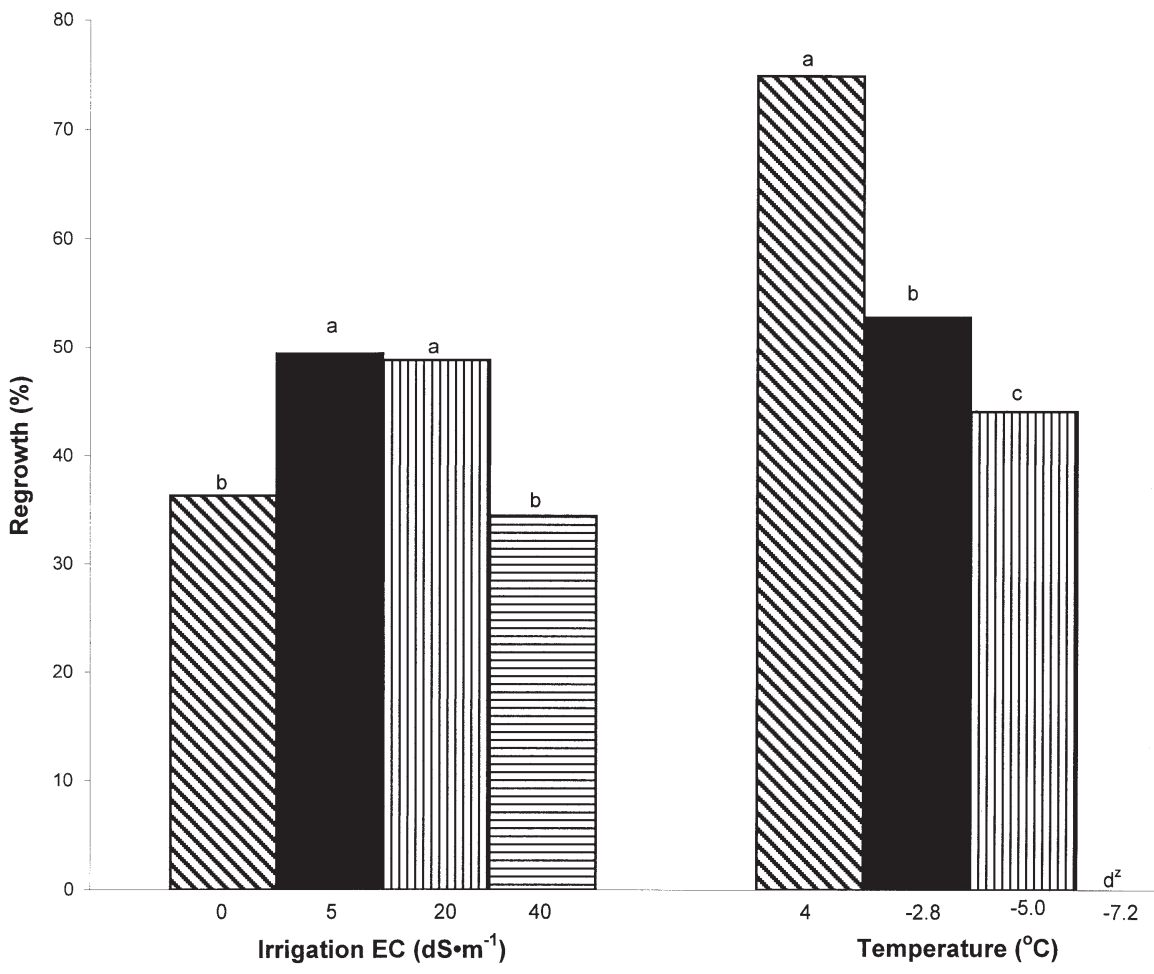

Fig. 5. Effect of salinity and temperature on percent regrowth following freezing. Bars with the same letter are not significantly different $(P<0.05)$.

${ }^{\mathrm{z}} \mathrm{No}$ regrowth occurred from plants experiencing $-7.2^{\circ} \mathrm{C}$.

eficial to bermudagrass. Turfgrass managers in the southern United States have been applying high rates of $\mathrm{K}$ fertilizers to bermudagrass turf for many years. McCarty (2001) explains that a $1 \mathrm{P}: 2 \mathrm{~K}$ ratio in leaves increases turfgrass cold hardiness. Because soil applications of $\mathrm{KCl}$ and $\mathrm{NaCl}$ will have similar effects on soil EC and subsequent plant responses, the authors speculate that positive effects of $\mathrm{KCl}$ applications to bermudagrass in the fall may be due to an increase of proline concentration in the plant. Future research should test this hypothesis directly. Other research should encompass the effect of one saline irrigation with $40 \mathrm{dS} \cdot \mathrm{m}^{-1}$ during acclimation and whether this is enough of an environmental stress to signal the plant's system to adequately increase proline levels without having a long term negative effect on the soil EC.

\section{Literature Cited}

Allakherdiev, S.I., Y. Nishiyama, Y. Suzuki, Y. Tasaka, and N. Murata. 1999. Genetic engineering of the unsaturation of fatty acids in membrane lipids alters the tolerance of Synechocystis to salt stress. Proc. Natl. Acad. Sci. USA. 96:5862-5867.

Anderson, J.A., C.M. Taliaferro, and D.L. Martin. 1993. Evaluating freeze tolerance of bermudag- rass in a controlled environment. HortScience 28(9):955.

Buchanan, B.B., W. Gruissem, and R.L. Jones. 2000. Biochemistry and molecular biology of plants. Amer. Soc. Plant Physiol., Rockville, Md.

Dean-Knox, D.E., D.A. Devitt, L.S. Verchick, and R.L. Morris. 1998. Physiological response of two turfgrass species to varying ratios of soil matric and osmotic potentials. Crop Sci. 38:175-181.

Dudeck, A.E. and C.H. Peacock. 1993. Salinity effects on growth and nutrient uptake of selected warm-season turf, p. 680-686. In: R.N. Carrow, N.E. Christians, and R.C. Shearman (eds.). Intl. Turfgrass Res. J. 7. Intertec Publ., Overland Park, Kans.

Gaugh, H.G. and C.H. Wadleigh. 1944. Effects of high salt concentration on growth of bean plants. Bot. Gaz. (Chicago) 105:379-387.

Hincha, D.K. 1994. Rapid induction of frost hardiness in spinach seedlings under salt stress. Planta. 194:274-278.

Holmstrom, K., S. Somersalo, A. Mandal, T.E. Palva, and B. Welin. 2000. Improved tolerance to salinity and low temperature in transgenic tobacco producing glycine betaine. J. Expt. Bot. 51:177-185.

Jain, M., G. Mathur, and N.B. Sarin. 2001. Ameliorative effects on salt stress-induced lipid peroxidation in cell lines of groundnut (Arachis hypogaea L.). Plant Cell Rpt. 20:463-468.

Mancino, C. and I.L. Pepper. 1994. Effects of wastewater on the turfgrass/soil environment. In: J.T.
Snow, M.P. Kenna, K.S. Erusha, M. Henry, C.H. Peacock, and J.R. Watson (eds.). Wastewater reuse for golf course irrigation. Lewis Publ., Chelsea, Mich.

Marcum, K.B. and C.L. Murdoch. 1994. Salinity tolerance mechanisms of six C4 turfgrasses. J. Amer. Soc. Hort. Sci. 119:779-784.

Marcum, K.B. 1999. Salinity tolerance mechanisms of grasses in the subfamily Chloridoideae. Crop Sci. 39:1153-1160.

McCarty, L.B. 2001. Best golf course management practices. Prentice-Hall, Upper Saddle River, N.J.

Meyer, M.J., M.A.L. Smith, and S.L. Knight. 1989. Salinity effects of St. Augustinegrass: A novel system to quantify stress response. J. Plant Nutr. 12:893-908

Morris, K. 2002. National bermudagrass test - 1997. Final report 1997-2001. NTEP No. 02-7.

Munshaw, G.C., D.W. Williams, and P.L. Cornelius. 2001. Management strategies during the establishment year enhance production and fitness of seeded bermudagrass stolons. Crop Sci. 41:1558-1564.

Nilsen, E.T. and D.M. Orcutt. 1996. The physiology of plants under stress. Wiley, New York.

Philley, H.W., J.V. Krans, J.M. Goatley, Jr., and V.L. Maddox. 1999. Turf performance of seeded bermudagrass cultivars in Mississippi. Mississippi Agr. and For. Expt. Sta. Aug. 1999. Bul. 1088.

Qian, Y.L., M.C. Engelke, and M.J.V. Foster. 2000. Salinity effects on zoysiagrass cultivars and experimental lines. Crop Sci. 40:488-492.

Saeed, M.A. 2000. Effect of irrigation with saline water on cotton plants of Giza 83 cultivar. Egyptian J. Agr. Res. 78:2029-2045.

Schmidt, R.E. and D.R. Chalmers. 1993. Late summer to early fall application of fertilizer and biostimulants on bermudagrass, p. 715-721. In: R.N.Carrow, N.E. Christians, and R.C. Shearman (eds.). Intl. Turfgrass Res. J. 7. Intertec Publ., Overland Park, Kans.

Syvertsen, J.P. and M.L. Smith. 1983. Environmental stress and seasonal changes in proline concentration in citrus tree tissues and juice. J. Amer. Soc. Hort. Sci. 108:861-866.

Syvertsen, J.P. and G. Yelenosky. 1988. Salinity can enhance freeze tolerance of citrus rootstock seedlings by modifying growth, water relations, and mineral nutrition. J. Amer. Soc. Hort. Sci. 113:889-893.

Taiz, L. and E. Zeiger. 1998. Plant physiology. The Benjamin/Cummings Publ., Redwood City, Calif.

Vieira Santos, C.L., A. Campos, H. Azevedo, and G. Caldeira. 2001. In situ and in vitro senescence induced by $\mathrm{KCl}$ stress: Nutritional imbalance, lipid peroxidation and antioxidant metabolism. J. Expt. Bot. 52:351-360.

Yu, B., H. Gong, and Y. Liu. 1998. Effects of calcium on lipid composition and function of plasma membrane and tonoplast vesicles isolated from roots of barley seedlings under salt stress. J. Plant Nutr. 21:1589-1600.

Zhang, X. and R.E. Schmidt. 2000. Application of trinexapac-ethyl and propiconazole enhances superoxide dismutase and photochemical activity in creeping bentgrass (Agrostis stolonifera var. palustris). J. Amer. Soc. Hort. Sci. 125:47-51. 